\title{
EFFECT OF SURFACE, SUBSURFACE AND DEEP SEWAGE DRIP IRRIGATION SYSTEMS ON EMITTERS PERFOMANCE AND WATER USE UTILIZATION FOR DATE PALM
}

\author{
M. A. Kassem*and F.A Gomaa**
}

\begin{abstract}
The objectives of this study are to investigate the effect of surface, subsurface and deep sewage drip irrigation systems on emitter performance and water use utilization of Date Palm(Sukariah $\boldsymbol{C V}$ )with different depths of irrigation water. These depths of applied water were 100\%, 75\% and 50\% of reference evapotranpiration "ETo". The results showed that the values of mean emitter discharge $(\boldsymbol{q})$, the relative emitter discharge $(\boldsymbol{R})$ and the reduction of discharge $\left(\boldsymbol{q}_{r}\right)$ is greatly influenced by irrigation system in comparison with irrigation water depth. The values of emitters performance $\boldsymbol{q}^{-}, \boldsymbol{R}, \boldsymbol{q r}$ for surface drip (DI) and deep sewage drip irrigation (DSDI) treatments were greater than those for subsurface drip (SDI) treatments. The values of emitter performance of DI and DSDI treatments had a higher values of distribution uniformity(DU)for all irrigation water depths treatments and for total irrigation time comparing with SDI. The value of Date Palm yield increased for DSDI treatment compared with those of DI or SDI treatments. The minimum value of Date Palm yield was $103 \mathrm{~kg} /$ tree for the treatment (DI , 0.5 ETo ), while the maximum values of Date Palm yield were 175 and 172 $\mathrm{kg} / \mathrm{tree}$ for the treatments (DSDI, 1.0 ETo ) and (DSDI, 0.75 ETo ), respectively. The maximum values of water use efficiency (WUE) were 1.34 and $1.31 \mathrm{~kg} / \mathrm{m} 3$ for the treatments (DSDI, 0.5 ETo ) and (DSDI, 0.75 ETo),
\end{abstract} Keywords: drip irrigation, emitter performance, Date Palm, uniformity

\section{INTRODUCTION}

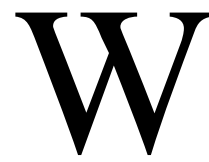
ater resource management is becoming a critical issue of the land management policies in Arabian Peninsula. The predicted climate changes will result in an increase in duration and intensity of summer drought. Hence, there is an urgent need to improve our knowledge concerning the water use and response

* Prof., Ag. Eng. Dept., Fac. of Ag.., Cairo Univ.( Now, contracted Qassem Univ.)

** Assoc. Prof., Soil \&water Dept., Fac. of Ag., Cairo Univ.( contracted Qassem Univ.) 
to drought of the main perennial vegetation types such as date palm and fruit trees. Date palm trees at Al-Qassim province represent $24 \%$ of the total area of Date Palm trees in Saudi Arabia. More important, irrigation should be applied in a controlled manner in order to provide an optimum situation for crop transpiration and to avoid evaporation and percolation losses(Guo et al., 2006). Subsurface drip irrigation was the best method of supplying uniform soil moisture in the root zone to plant. Furthermore, it would position the supply of nutrients in the center of the root zone where the water content is relatively high and steady with time (Phene et al., 1991). Subsurface drip irrigation provides a great potential for increasing crop production since it minimizes the losses of irrigation water depth which gives a way for expanding the cultivated areas. (kassem , 2000).

Subsurface drip irrigation (SDI) is one of effective irrigation methods, but it is easy to clog(Peng et al., 2006). It is the key problem of the SDI system whether emitters are clogged. An investigation of emitter clogging was conducted in a SDI system, which had been running for 8 years. Clogging rates of Labyrinth emitter, mini-pipe and orifice reached $16.67 \%, 25 \%$ and 63.89\%, respectively (Lamm and Camp, 2007). De Kreij et al. (2003) found that the tube emitter system with laminar flow suffers more severe clogging than the labyrinth system with turbulent flow, because laminar flow is predisposed to clogging. Capra and Scicolone (2004) found that vortex emitters are more sensitive to clogging than labyrinth emitters. Emitter clogging greatly reduces the water distribution uniformity in irrigated fields(Puig-Bargues et al., 2005). These clogging were mainly caused by attached granules(Nakayama et al., 2007). There are many design and management similarities to surface drip irrigation (DI), but there are also some unique differences that affect uniformity, operation, and system longevity(Puig-Bargues et al., 2005). A typical SDI system often requires additional components, compared to DI, such as flush lines, additional 
air/vacuum relief valves, and pressure gauges and a flow meter for system monitoring(Ahmed et al., 2007).

To keep SDI advantages and reduce emitter clogging, a new irrigation method was suggested to irrigate Date Palm trees, this method is called deep sewage drip irrigation system (DSDI). Therefore, the objectives of this study are to investigate the effect of surface, subsurface and deep sewage drip irrigation systems on emitter performance and water use utilization of Date Palm with different depths of applied water, the depths of applied water were, $100 \%, 66 \%$ and $50 \%$ of reference evapotranspiration $\left(\mathrm{ET}_{0}\right)$.

\section{MATERIALS AND METHODS}

\section{Layout of Experimental field}

The current study was carried out at the Research Station, Faculty of Agriculture and Veterinary Medicine, Qassim University, Kingdom of Saudi Arabia during 2009 and 2010 growing seasons. The geographical location of the farm is $26^{\circ} 18^{\prime} \mathrm{N}$ latitude, $43^{\circ} 58^{\prime} \mathrm{E}$ longitude and $720 \mathrm{~m}$ altitude. The region has an arid hot climate. Field measurements were taken during the productive cycle of a 15 years old date palm tree "Sukariah" variety . The Date Palm trees had an average height of trunk $1.8 \mathrm{~m}$; average diameter of trunk $0.69 \mathrm{~m}$; average long of palm leaves is $3.05 \mathrm{~m}$ and average number of leaves are 56 per a tree. The date palm trees spaced of $8.0 \mathrm{~m}$ between rows by $8.0 \mathrm{~m}$ between trees. A split plot design with five replicates was used in this study. Main plots consisted of three irrigation systems; surface drip irrigation(D.I), subsurface drip irrigation (S.D.I), and deep sewage drip irrigation (D.S.D.I). Sub-plots consisted of three depths of irrigation water; $100 \%, 75 \%$ and $50 \%$ of reference evapotranspiration $\left(\mathrm{ET}_{0}\right)$. Surface, subsurface and deep sewage drip irrigation systems with computerized control were designed and built for this experimental field. Pressure regulator, valve and discharge rate gauge were fixed at the inlet line for each treatment.

For surface drip irrigation system each Date Palm tree was irrigated by a lateral line around a tree in a circle shape. The distance between the lateral line and the date palm trunk was $1.5 \mathrm{~m}$, ten labyrinth emitters were 
used to irrigate the date palm tree. The discharge rate was $8 \mathrm{lit} / \mathrm{h}$ for each emitter at inlet pressure one bar. The distance between two sequence emitters on lateral line was $1.0 \mathrm{~m}$. For subsurface drip irrigation system, the same laterals were used and fixed at $60 \mathrm{~cm}$ from soil surface. While for deep sewage drip irrigation system, ten P.V.C pipes 2 "were fixed vertically to $0.6 \mathrm{~m}$ depth. One emitter was put in each pipe. The distance between two sequence pipes was $1.0 \mathrm{~m}$.

\section{Experimental measurements}

To determine the mean emitter discharge $\left(\mathbf{q}^{-}\right)$, the relative emitter discharge $(\mathbf{R})$ and the reduction of discharge $\left(\mathbf{q}_{\mathbf{r}}\right)$ in percentage, the discharge of each emitter was measured at the beginning of the experiments for new emitters and at the end of experiments for the same emitters. The discharge of each emitter was measured by using the containers. Before each measurement, the 10-Liter containers were put precisely beneath the emitters. After $1 \mathrm{~h}$ operation of the system, the water volume of each container with emitted water was measured using a graduate jar. The emitter discharge was recorded in volume per unit time, $(1 / \mathrm{h})$ without considering the impact of environmental factors.

Before starting the experimental work, a trench $(2.5 \mathrm{~m}$ depth, $1.0 \mathrm{~m}$ width and $2.0 \mathrm{~m}$ length) was open in the experimental plot for extracting undisturbed soil samples, with three replicates, at the same soil depths. These soil samples were used for determining the soil texture (soil mechanical analysis), field capacity, wilting point and bulk density according to Anter et. al., (1987).. All these measurements were measured in the Soil Laboratory, Faculty of Agriculture and Veterinary Medicine, Qassim University. The results indicated that soil type of this farm is classified as a sandy soil, $96.3 \%$ sand, $1.8 \%$ silt and $1.9 \%$ clay. The field capacity was $13 \%$ by volume, the wilting point was $4 \%$ by volume and the soil bulk density was $1510 \mathrm{~kg} / \mathrm{m}^{3}$. The soil without groundwater table to a depth of $3 \mathrm{~m}$. The irrigation water was obtained from local well. The irrigation water has a $\mathrm{pH}$ of 7.4 and total soluble salts of $850 \mathrm{ppm}$. Sodium adsorption ratio (SAR) was 2.41 .

The monthly climatic averages for five years (2004-2008) of Burida station climatologically were determined, These values were used to 
determine the daily reference evapotranspiration $\left(\mathrm{ET}_{0}\right)$ by PenmanMonteith's model.

\section{Assessment of emitter performances and irrigation system}

The criteria used for assessing the emitter were mean emitter discharge $\left(\mathbf{q}^{-}\right)$, the relative emitter discharge $(\mathbf{R})$, the reduction of discharge $\left(\mathbf{q}_{\mathbf{r}}\right)$, the percentage of partially and completely clogged emitters. While, for assessing the irrigation systems, the water application efficiency (AE) and the water use efficiency (WUE)criteria were used.

The reduction of the mean emitter discharge in percentage $\left(\mathbf{q}_{\mathbf{r}}\right)$ and the relative emitter discharge $(\mathbf{R})$ were calculated from equations (1) and (2) ,respectively, according to(Lamm and Camp, 2007).

$$
\begin{aligned}
& \left.q_{r=100 *(1}-\frac{q^{-}}{q_{\text {in }}}\right)=100 *(1-\mathrm{R}) \text { Eq. } 1 \\
& R=\frac{q^{-}}{q_{1 n}} \mathrm{Eq} .2
\end{aligned}
$$

Where:

$\mathrm{q}_{\mathrm{r}}=$ reduction of the mean emitter discharge, \%;

$\mathrm{q}^{-}=$mean emitter discharges of each lateral for each measurement, $1 / \mathrm{h}$;

$\mathrm{q}_{\text {in }}=$ mean discharge of 100 new emitters at the same operation pressure, $1 / \mathrm{h}$;

$\mathrm{R}=$ relative emitter discharge, dimensionless.

The distribution uniformity (DU) was calculated from equation (3) according to(Keller and Karmeli, 1974)

$$
\mathrm{DU}=100 *\left(\frac{q_{\min 1 / 4}}{q l^{-}}\right) \mathrm{Eq} .3
$$

Where:

DU = distribution uniformity, \%;

$\mathrm{q}_{1}^{-}=$mean emitter discharge in the same lateral, $1 / \mathrm{h}$;

$\mathrm{q}_{\min 1 / 4}=$ mean discharge of lower quartile, $1 / \mathrm{h}$.

The water use efficiency (WUE) has been used to evaluate various irrigation regimes which produce maximum yield per unit of water applied to the field. The water use efficiency (WUE) was determined from equations (4) according to (Begg and Turner, 1976).

$$
\mathrm{WUE}=(\mathrm{Y} / \mathrm{Aw})
$$

Eq.4

Where: 
WUE = water use efficiency, $\mathrm{kg} / \mathrm{m}^{3}$;

$\mathrm{Y} \quad=$ the yield production, $\mathrm{kg} / \mathrm{m}^{2}$;

Aw $=$ the total depth of applied water $\mathrm{m}^{3} / \mathrm{m}^{2}$.

\section{RESULTS AND DISCUSSION}

\section{1- Depth of applied water:}

The observed monthly average values of the climatic variables for experimental sit are shown in table (1). These data were used to determine daily reference evapotranspiration (ETo), table (1) .The data revealed that the mean daily values of reference evapotranspiration (ETo) were affected by climatic conditions. The mean maximum monthly temperature was $32.05^{\circ} \mathrm{C}$ during the summer months from June to September, while the lowest main monthly temperature was $13.91{ }^{\circ} \mathrm{C}$ for December to February. The region also presents an irregular rainfall regime with a rainy season period. The mean maximum monthly rainfalls were $6.24 \mathrm{~mm} /$ day and $5.7 \mathrm{~mm} /$ day in the months November and March, respectively. Wind speed increased from February to September and then decreased toward the end of the observational period, with an average value of $2.03 \mathrm{~m} / \mathrm{s}$, for the whole experimental period. The maximum mean daily values of net radiation, sunshine and wind speed occurred in July.

The mean depths of the irrigation water $\mathrm{mm}$ /day for each month for treatments 1.0 ETo, 0.75 ETo and 0.5 ETo are shown in Figure (1).The data revealed that The maximum value of irrigation water depth was 10.6 $\mathrm{mm} /$ day in July for treatment 1.0 ETo. In July month, the air temperature; wind speed and sun shine were high and the relative humidity was low, Table(1). The minimum values of irrigation water depthwere 3.3 and $3.35 \mathrm{~mm} /$ day in January and December months, respectively, where the climatic condition was inversed of that in July month. Also, the maximum and minimum applied irrigation water depth occurred in the periods of high and low evaporative rates, respectively. The same trend was found for treatments 0.75 ETo and 0.5 ETo. For irrigation water depth treatments, the values of irrigation time were different from treatment to another, Table (2). The values of total 
irrigation time for one year were $1548 \mathrm{~h}, 1161 \mathrm{~h}$ and $774 \mathrm{~h}$ for treatments 1.0 ETo, 0.75 ETo and 0.5 ETo, respectively.

Table (1): The average monthly values of daily air temperature $\left(T_{\mathrm{a}}\right)$, relative humidity $(\mathrm{RH})$, wind speed $(U)$, sunshine $(n)$ and net radiation (Rn) at experimental sit, Burida city, Al Qassem zone, Kingdom of Saudi Arabia during years (2004-2008).

\begin{tabular}{|c|c|c|c|c|c|}
\hline Month & $\begin{array}{c}\mathbf{T}_{\mathbf{a}} \\
\left({ }^{\mathbf{}} \mathbf{C}\right)\end{array}$ & $\begin{array}{c}\mathbf{R H} \\
(\mathbf{\%})\end{array}$ & $\begin{array}{c}\mathbf{U} \\
(\mathbf{m} / \mathbf{s})\end{array}$ & $\mathbf{n}(\mathbf{h})$ & $\begin{array}{c}\mathbf{R n} \\
\mathbf{w} / \mathbf{m}^{\mathbf{2}}\end{array}$ \\
\hline Feb. & 14.65 & 54.00 & 1.66 & 7.10 & 582.66 \\
\hline Mar. & 21.35 & 46.23 & 1.86 & 8.20 & 678.67 \\
\hline Apr. & 21.35 & 39.54 & 2.01 & 8.41 & 737.78 \\
\hline May. & 28.90 & 32.21 & 2.00 & 8.62 & 762.60 \\
\hline Jun. & 32.00 & 24.45 & 2.34 & 10.81 & 764.40 \\
\hline Jul. & 32.45 & 23.00 & 2.57 & 12.20 & 751.87 \\
\hline Aug. & 32.35 & 23.10 & 2.50 & 10.53 & 721.84 \\
\hline Sep. & 31.40 & 24.50 & 2.26 & 10.23 & 639.87 \\
\hline Oct. & 26.00 & 39.00 & 2.04 & 7.34 & 563.71 \\
\hline Nov. & 17.65 & 50.20 & 1.89 & 7.92 & 468.06 \\
\hline Dec. & 14.00 & 57.50 & 1.83 & 7.86 & 434.86 \\
\hline Jan. & 13.10 & 61.82 & 1.41 & 7.10 & 477.92 \\
\hline
\end{tabular}

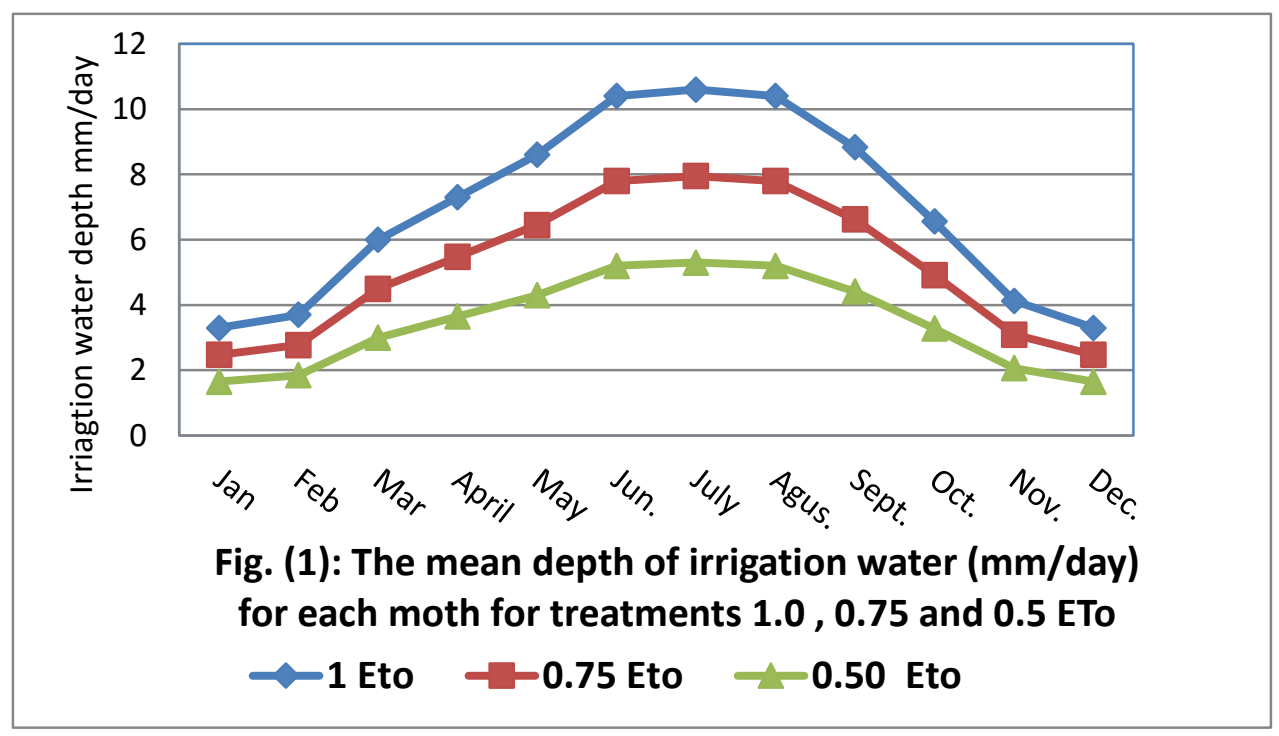


Table (2): Total irrigation depth and total operation time for treatments 1.0 ETo, 0.75 ETo and 0.5 ETo,

\begin{tabular}{|c|c|c|}
\hline Treatment & Total irrigation depth, $\mathbf{m m}$ & Total irrigation time, $\mathbf{h}$ \\
\hline $\mathbf{1}$ ETo & 2493 & 1548 \\
\hline $\mathbf{0 . 7 5}$ ETo & 1869.75 & 1161 \\
\hline $\mathbf{0 . 5 0}$ ETo & 1246.5 & 774 \\
\hline
\end{tabular}

\section{2- Effect of irrigation system and irrigation water depth on emitter performance}

The results of the effect of irrigation system and irrigation water depth on emitter performance are shown in Figure $(2 \mathrm{a}, \mathrm{b}, \mathrm{c})$. The results showed high significant effect of these factors on mean emitter discharges $\boldsymbol{q}^{-}$, emitter discharges reduction qr and relative emitter discharge R. The mean emitter discharges $\mathbf{q}^{-}$for irrigation system treatments and irrigation water depth treatments ;1.0 ETo, 0.75 ETo and 0.5 ETo at experiment end and for new emitters are shown in Figure (2-a). The values of $\mathbf{q}^{-}$varies with irrigation system and irrigation water depth. The values of $\mathbf{q}^{-}$for subsurface drip irrigation(SDI) treatment decreased greatly with the irrigation water depth in comparison with that of surface drip irrigation (DI) and deep sewage drip irrigation (DSDI) treatments. The values of $\mathbf{q}^{-}$is greatly influenced by irrigation system in comparison with irrigation water depth. The values of $\mathbf{q}^{-}$for (SDI) treatment decreased greatly with increasing irrigation water depth in comparison with that of (DI) and (DSDI) treatments. For 0.5 ETo treatment, $774 \mathrm{~h}$ of irrigation time, there are no significant differences $(P>0.05)$ for the values of $\mathbf{q}^{-}$between the (DI), (SDI) and (DSDI) treatments. For $\mathbf{0 . 7 5}$ ETo treatment, $1116 \mathrm{~h}$ of irrigation time, the difference in the values of $\mathbf{q}$ between the (DI) and (DSDI) treatments is not significant $(P>0.05)$, while the values of $\boldsymbol{q}$ for the SDI treatment decreases greatly due to severe clogging and it is about $12 \%$ lower than the discharge for the (DI) treatment. For (1.0 ETo) treatment, $1548 \mathrm{~h}$ of irrigation time, the difference in the values of $\mathbf{q}$ between the (DI) and (DSDI)treatments is not significant $(P>0.05)$, while the values of $\mathbf{q}^{-}$for the SDI treatment decreases very greatly due to severe clogging and is about $30.5 \%$ lower than the discharge for the (DI) treatment. 
The reduction of mean emitter discharges $\mathbf{q} \mathbf{r}$ for irrigation system treatments and irrigation water depthtreatments;1.0 ETo, 0.75 ETo and 0.5 ETo at experiment end are shown in Figure (2-b). At the end of the experiment, the maximum values of the reduction of mean emitter discharges $\mathbf{q r}_{\mathbf{r}}$ were $27 \%$ and $16 \%$ for treatments of (SDI) using 1.0 ET0 and (SDI ) using 0.75 ET0. While the values of $\mathbf{q r}$ were less than $5.2 \%$ for treatments DI and DSDI with any irrigation depths treatments. discharge reductions can primarily be explained by emitter clogging. (Ravina et al., 1997; Liu and Huang, 2009). Decreasing the values of $\mathbf{q} \mathbf{r}$, the percentages of emitter clogging were increased.( Liu and Huang, 2009).

The relative emitter discharge $\mathbf{R}$ for irrigation system treatments and irrigation water depth treatments 1.0 ETo, 0.75 ETo and 0.5 ETo at experiment end are shown in Figure (2-c).For DI and DSDI treatments, , the values of $\mathbf{R}$ are higher than 0.79 for all irrigation water depth treatments 1.0 ETo, 0.75 ETo and 0.5 ETo. So, the values of $\mathbf{R}$ of these treatments for irrigation times from 774 to $1548 \mathrm{~h}$ are in the range of the high discharge class. Capra and Scicolone (2007) divided the relative emitter discharge into three classes, high discharge class $(\mathbf{R} \geq$ 0.79 ), moderate discharge class ( $\mathbf{R}$ between 0.79 and 0.61 ) and low discharge class ( $\mathbf{R}<0.61$ ). For (SDI) treatment, the values of $\mathbf{R}$ are higher than 0.79 for irrigation water depth treatments, 0.75 ETo and 0.5 ETo where the times of irrigation were 1126 and $774 \mathrm{~h}$, respectively. While for irrigation water depth treatment 1.0 ETo $1458 \mathrm{~h}$ irrigational time the $\mathbf{R}$ values decreased than 0.79 to reach 0.72 at the irrigation time $1458 \mathrm{~h}$.From these results we can conclude that by increasing the irrigation times, the values of $\mathbf{R}$ are decreased for all treatments. By decreasing the values of $\mathbf{R}$, the emitters clogging degree were increased, ( Capra and Scicolone ,2004 ). (DI) and (DSDI) treatments increased the values of $\mathbf{R}$ and decreased the emitter-clogging degree compared to (SDI). At the end of the experiment, the minimum value of $\mathbf{R}$ was 0.72 for treatment of (SDI)with irrigation water depth treatment 1.0 ETo $1458 \mathrm{~h}$ irrigation time. While the maximum values of $\mathbf{R}$ were 0.98 and 0.97 for (DI) and (DSDI) treatments with irrigation water depth treatment 0.5 ETo $774 \mathrm{~h}$ irrigation time, respectively. 

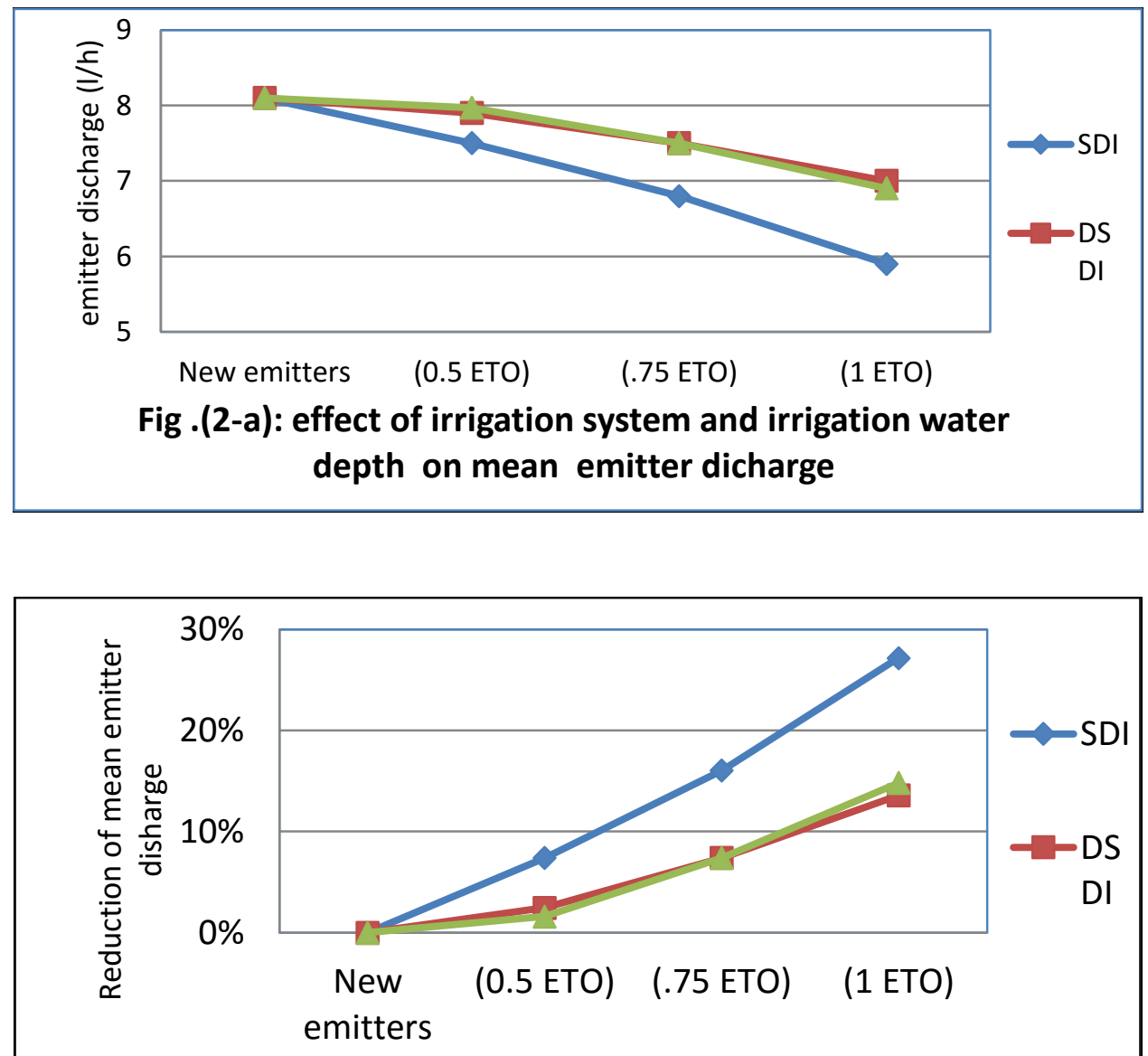

Fig . (2-b): effect of irrigation system and irrigation water depth on reduction of mean emitter

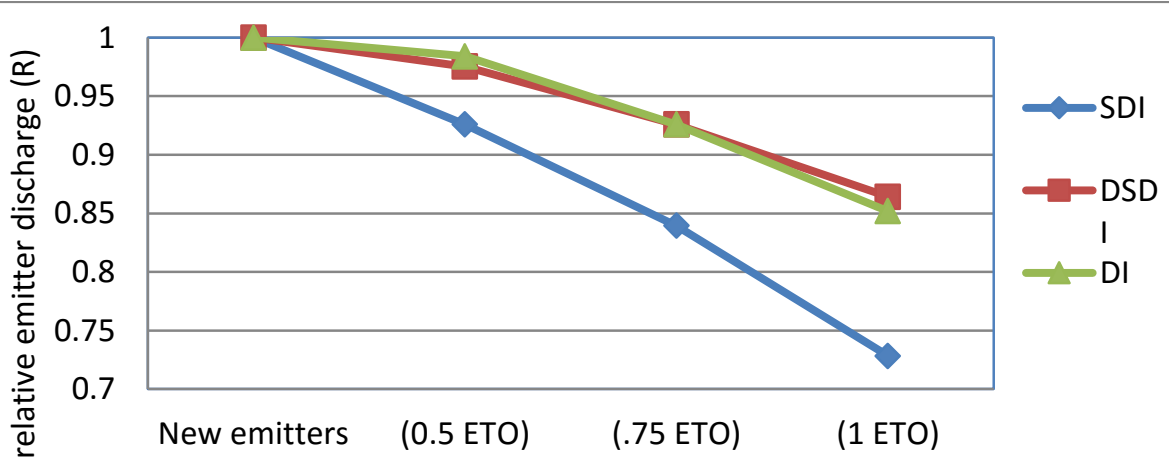

Fig .(2-c): effect of irrigation system and irrigation water depth on relative emitter disharge 


\section{3- Effect of irrigation system and irrigation water depth on water distribution uniformity DU.}

The results of the effect of irrigation system and irrigation water depth on water distribution uniformity DU are shown in Figure (3).Similar to the relative emitter discharge $\mathbf{R}$, the $\mathbf{D U}$ values varies with irrigation system and irrigation water depth. The values of DU for (SDI) treatment decreased greatly with irrigation water depth treatment (with the increase of irrigation time) in comparison with those of (DI) and (DSDI) treatments. For (DI) and (DSDI) treatments using 0.5 ETo irrigation water depth had the highest values of DU greater than $88 \%$ in the entire experimental period. For (DI) and (DSDI) treatments, the difference in values of DU are not significant for all irrigation water depth treatments. At the end of the experiment, the DU values of (DSDI) treatments are 94\%, 91.5\% and $89 \%$ for irrigation water depth treatments 0.5 ETo, 0.75 ETo and 1.0 ETo, respectively. While the DU values of (SDI) treatment are $91 \%, 88 \%$ and $79 \%$, for irrigation water depth treatments 0.5 ETo, 0.75 ETo and 1.0 ETo, respectively. From the above mentioned, it is clear that DI) and (DSDI)treatments had a higher values of DU for all irrigation water depth treatments and for total irrigation time comparison with (SDI).

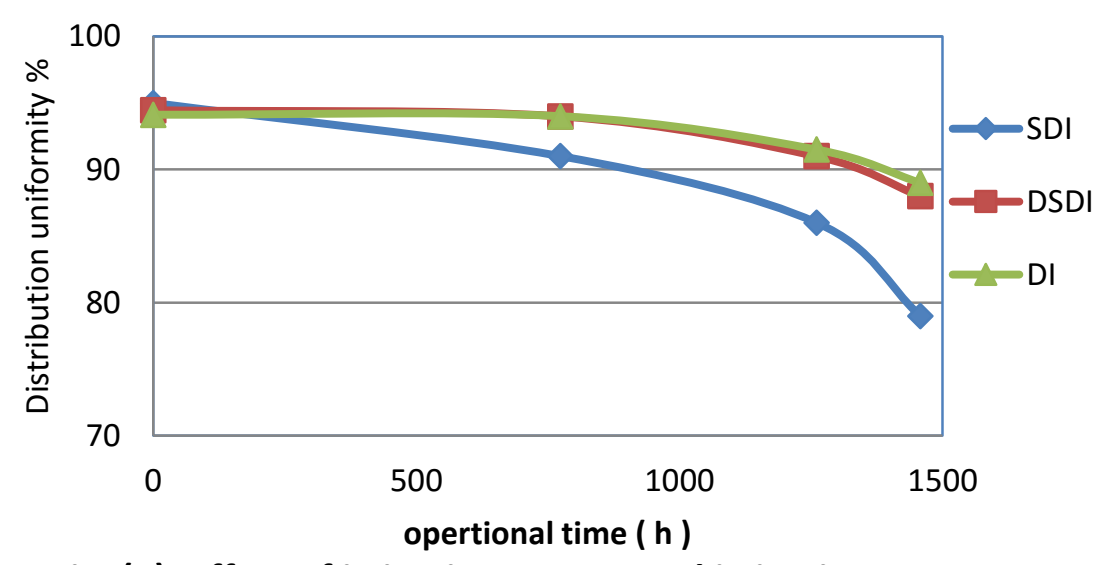

Fig. (3): effect of irrigation system and irrigation water depth on distribution uniformity 


\section{4- Effect of irrigation system and irrigation water depth on yield and water use efficiency of Date palm}

The values of Date palm yield and water use efficiency (WUE) for each treatments are shown in Table (3). For (DSDI) the data revealed that the Date Palm yield increased by increasing the value of irrigation water depth from "0.5 ETo" to 0.75 ETo". There are no significant differences (P > 0.05) for the values of Date Palm yield for ."0.75 ETo" to "1.0 ETo" treatments. The same trend was found for (DI) and (SDI) treatments. At the same irrigation water depth (DSDI) treatment increased the Date Palm yield compared with those of (DI) or (SDI) treatments. Also, (SDI) treatment increased Date Palm yield compared with that of (DI) treatment. The minimum value of Date Palm yield was $103 \mathrm{~kg} /$ tree for the treatment (DI, 0.5 ETo), where the trees under high water stress and water evaporation losses was relatively high. While the maximum values of Date palm yield were 175 and $172 \mathrm{~kg} /$ tree for the treatments (DSDI , 1.0ETo ) and (DSDI, 0.75ETo ), respectively. In these treatments, the trees had their total water requirements. Kassem, 2009 estimated crop coefficient of Date palm trees (Sukariah CV)and was found 0.63. Also, soil moisture content in the root zone is relatively high and steady with time(Phene et al., 1991). The values of Date palm yield of (SDI) treatment were found moderate 152 and $150 \mathrm{~kg} /$ tree for (SDI , 0.75 ETo ) and (SDI , 1.0 ETo ) treatments, respectively. The reduction of yield may be due to decrease emitters performance. The DU values of these treatments were $88 \%$ and $79 \%$, respectively.

The water use efficiency (WUE)decreased as by increasing the value of irrigation water depth from "0.5 ETo" to $0.75 \mathrm{ETo".} \mathrm{There} \mathrm{are} \mathrm{no}$ significant differences $(\mathrm{P}>0.05)$ for the values of WUE for ."0.75 ETo" to "1.0 ETo" treatments. The same trend was found for (DI) and (SDI) treatments. At the same irrigation water depth (DSDI) treatment increased the WUE compared with those of (DI) or (SDI) treatments. Also, (SDI) treatment increased WUE compared with that of (DI) 
treatment. The minimum value of WUE was $0.79 \mathrm{~kg} / \mathrm{m}^{3}$ for the treatment (DI , 1.0 ETo ), where the water evaporation losses was relatively high. While the maximum values of WUE were 1.34 and $1.31 \mathrm{~kg} / \mathrm{m}^{3}$ for the treatments (DSDI , 0.5ETo ) and (DSDI , 0.75 ETo ), respectively. The values of WUE of (SDI) treatment were found moderate 1.25 and 1.13 $\mathrm{kg} / \mathrm{m}^{3}$ for (SDI , 0.5 ETo ) and (SDI , 0.75ETo ) treatments, respectively.

From above mention, we can concluded that deep sewage drip irrigation system had high emitter performance as surface drip irrigation comparison with subsurface drip irrigation. Also, deep sewage drip irrigation system had high WUE comparison with subsurface drip irrigation and surface drip irrigation.

Table (3): Effect of irrigation system and irrigation water depth on yield and water use efficiency of Date Palm.

\begin{tabular}{|c|c|c|c|}
\hline \multirow{4}{*}{ Irrigation system } & $\begin{array}{c}\text { irrigation } \\
\text { water depth }\end{array}$ & Yield (kg) & $\begin{array}{c}\mathbf{W U E} \\
\mathbf{K g} / \mathbf{m}^{\mathbf{3}}\end{array}$ \\
\hline $\begin{array}{c}\text { deep sewage drip } \\
\text { irrigation(DSDI) }\end{array}$ & $0.5 \mathrm{ETo}$ & 120 & 1.34 \\
\cline { 2 - 4 } & $0.75 \mathrm{ETo}$ & 175 & 1.31 \\
\cline { 2 - 4 } & $1.0 \mathrm{ETo}$ & 172 & 0.97 \\
\hline \multirow{2}{*}{$\begin{array}{c}\text { Surface drip } \\
\text { irrigation (DI) }\end{array}$} & $0.5 \mathrm{ETo}$ & 105 & 1.17 \\
\cline { 2 - 4 } & $0.75 \mathrm{ETo}$ & 145 & 1.08 \\
\hline \multirow{2}{*}{$\begin{array}{c}\text { Subsurface } \\
\text { drip }\end{array}$} & $1.0 \mathrm{ETo}$ & 140 & 0.79 \\
\cline { 2 - 4 } irrigation(SDI) & $0.5 \mathrm{ETo}$ & 110 & 1.23 \\
\cline { 2 - 4 } & $0.75 \mathrm{ETo}$ & 152 & 1.13 \\
\hline
\end{tabular}

\section{CONCLUSION}

From this investigation the following conclusions can be made:

1. The maximum value of irrigation water depth was $10.6 \mathrm{~mm} /$ day in July month for treatment "1.0 ETo". The minimum value of irrigation water depth were 3.3 and $3.35 \mathrm{~mm}$ /day in January and December months, respectively. 
2. The values of mean emitter discharges $\boldsymbol{q}$-for (SDI) treatment decreased greatly with the irrigation water depth in comparison with that of (DI) and (DSDI) treatments. The values of $\mathrm{q}^{-}$for the SDI treatment decreases very greatly and is about $30.5 \%$ lower than the discharge for the (DI) treatment.

3. The maximum values of reduction of mean emitter discharges $(\mathbf{q} \mathbf{r})$ were $27 \%$ and $16 \%$ for treatments of (SDI) using 1.0 ET0 and (SDI ) using 0.75 ET0, respectively. While the values of $\mathbf{q r}_{\mathbf{r}}$ were less than $5.2 \%$ for treatments (DI) and (DSDI) with any irrigation depths treatments.

4. The minimum value of relative emitter discharge $\mathbf{R}$ was $0 . .72$ for treatment of (SDI) with irrigation water depth treatment $\mathbf{1 . 0}$ ETo $1458 \mathrm{~h}$ irrigation time. While the maximum values of $\mathbf{R}$ were 0.98 and 0.97 for (DI) and (DSDI)treatments with irrigation water depth treatment $\mathbf{0 . 5}$ ETo $774 \mathrm{~h}$ irrigation time, respectively .

5. The values of water distribution uniformity (DU) for (SDI) treatment are $91 \%, 88 \%$ and $79 \%$, for irrigation water depth treatments 0.5 ETo, 0.75 ETo and 1.0 ETo, respectively. (DI) and (DSDI)treatments had a higher values of DU for all irrigation water depth treatments and for total irrigation time comparison with (SDI).

6. (DSDI) treatment increased the Date palm yield compared with those of (DI) or (SDI) treatments. Also, (SDI) treatment increased Date palm yield compared with that of (DI) treatment.

7. the maximum values of WUE were 1.34 and $1.31 \mathrm{~kg} / \mathrm{m}^{3}$ for the treatments (DSDI, 0.5 ETo ) and (DSDI, 0.75 ETo ) respectively.

\section{Acknowledgment}

Authors are grateful to Saudi Arabia Basic Industries corporation (SABC) for providing financial support for carrying out this work. 


\section{REFERENCES}

Ahmed, B. O., T. Yamamoto, H. Fujiyama and K. Miyamoto. 2007. Assessment of emitter discharge in micro irrigation system as affected by polluted water. Irrig. Drain Syst. 21: 97-107.

Anter, I. M.; A. Negm and M. I. Meacheal. 1987. Analysis methods of agricultural soils. Soil and Water Res. Inst. Res. Center, Tech. Reports 8/1986:1-22

Begg.J. E. and N. C. Turner. 1976. Crop Water Deficits. Advances in Agron.20pp.

Capra, A., B. Scicolone. 2004. Emitter and filter test for wastewater reuse by drip irrigation, Agric. Water Manage, 68 (2): 135-149.

Capra, A., B. Scicolone. 2007. Recycling of poor quality urban wastewater by drip irrigation systems. J. Cleaner Prod. 15, 15291534.

De Kreij, C., A. M. M. van der Burg and W. T. Runia. 2003. Drip irrigation emitter logging in Dutch greenhouses as affected by methane and organic acids. Agric. Water Manage, 60: 73-85.

Guo, X. Y., Z. Dong and H. L. Gong. 2006. Influence of reclaimed water irrigation on microbial community on lawn soil. Chin. Environ, Sci. 26 (4): 482-485.

Lamm, F.R., Camp, R.C. 2007. Micro irrigation for Crop Production. Design, Operation, and Management. Elsevier, Amsterdam, pp. 473551. 
Liu, H. and G. Huang. 2009. Laboratory experiment on drip emitter clogging with fresh water and treated sewage effluent. Agric. Water Manage. ,96 (5): 745-756.

Kassem. M. A. 2000. Comparative study for the effect of subsurface drip irrigation, surface drip irrigation and furrow irrigation systems on the growth and the yield of sunflower crop. Misr, J. Ag. Eng., 17 (2): 374387

Kassem. M. A. 2009. Water requirements and crop coefficient of Date Palm Trees "SukaRiah cv. Misr, J. Ag. Eng., 24(2): 339-359

Keller, J. and Karmeli, D. 1974. Trickle irrigation design parameters. Trans. ASAE 17 (4), 678-684.

Nakayama, F. S., B. J. Boman and D. J. Pitts. 2007. Micro irrigation for Crop Production. Design, Operation, and Management, Elsevier, Amsterdam, pp. 389-430.

Peng, Z., P. Yang, S. Ren and Y. Wang. 2006. Impact characteristics of reclaimed water irrigation on the growth rate, chlorophyll and carotenoids contents of lawn grasses.Trans. CSAE, 22 (10): 105-108.

Phene, C. J.; K. R. Davis; R. B. Humacher; B. Baryosef; B. Meek and J. Misaki. 1991. Effect of high frequency surface and subsurface drip irrigation on root distribution of sweet corn. Irrg. Sci.12(13): 135-140

Puig-Bargues, J., G. Arbat, J. Barragan and F. Ramirez de Cartagena. 2005. Hydraulic performance of drip irrigation subunits using WWTP effluents. Agric. Water Manage. 77: 249-262.

Ravina, I. , E. Paz, Z. Sofer, A. Marcu, A. Shisha, G. Sagi, Z. Yechialy and Y. Lev, .1997. Control of clogging in drip irrigation with stored treated municipal sewage effluent. Agric. Water Manage., 33 (2-3): pp. 127-137. 


\section{الملخص العربيى}

تأثير الري بالتثقيط السطحي وتحث السطحي وذو الرشح العميق على أداء

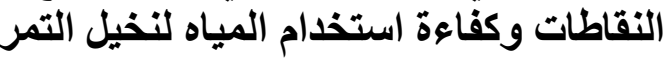

محمد عبد الوهاب قاسم * و فتحي عبد الحليم جمعة**

تمت هذه الدر اسة من خلال إجر اء تجربة حقلية على النخيل المثمر صنف السكري خلال عامي

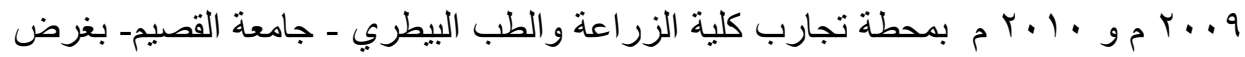
در اسة تأثير الري بالتنقيط السطحي(DI) و الري بالتنقيط تحت السطحي(SDI) و الري بالتنقيط ذو الرشح العميق(DSDI)(طريقة ري مقترحة) على أداء النقاطات وكفاءة استخدام المياه

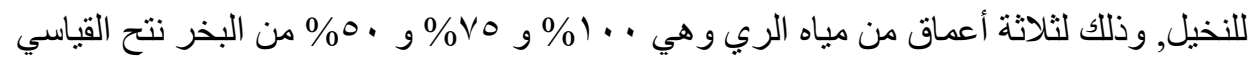

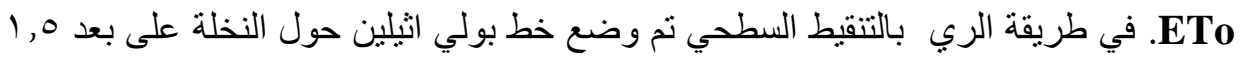

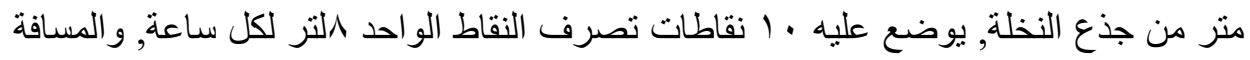

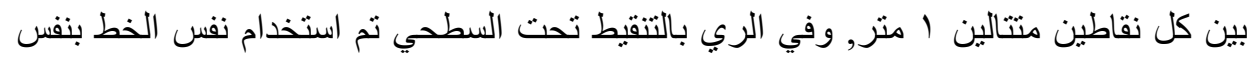

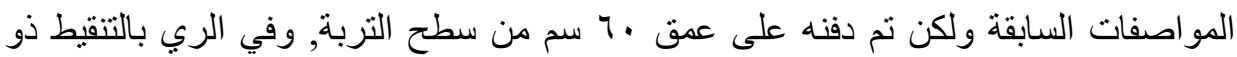
الرشح العميق تم تثييت عشرة مواسير من ال PVC راسيا لتصل إلى عمق · ج سم من سطح

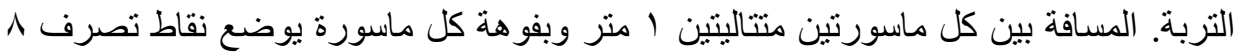
لتر/ساعة. تم تصميم وتنفيذ التجربة بطريقة القطع العشوائية الكاملة بحيث تشمل على أربعة معاملات رئيسية وثلاثة معاملات تحت رئيسية. بكل معاملة خمسة مكرر ات.

\section{وأوضحث أهم النتائج ما يلإ:-}

ا. . تحققت أعلى قيمة لعمق مياه الري المضافة ( 7, • ( مم/يوم ) في شهر يوليه لمعاملة

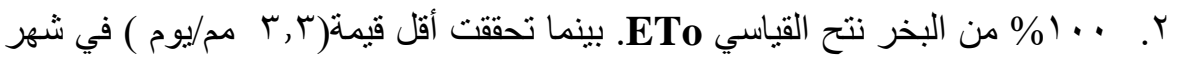

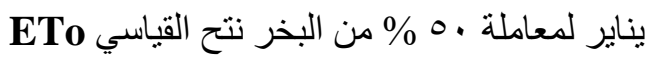

ץ. ت تتأثر قيم التصرف المتوسطة للنقاطات q بكل من معاملات نظام الري وعمق مياه

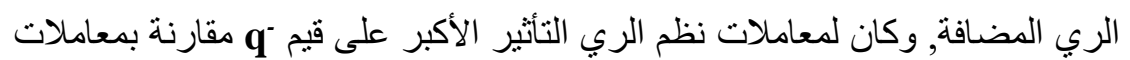

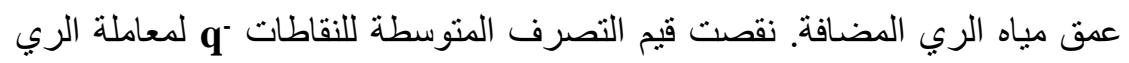

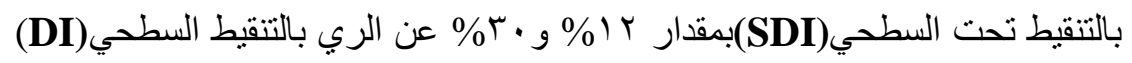

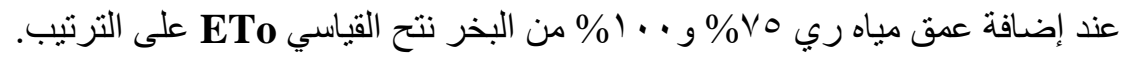

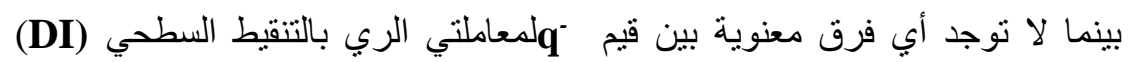
و الري بالتنقيط ذو الرشح العميق (DSDI), وذللك لجميع أعماق مياه الري المضافة.

* أستاذ بقسم الهندسة الزراعيةـ كلية الزراعةـ جامعة القاهرة. (متعاقد الآن مع جامعة القصيم)

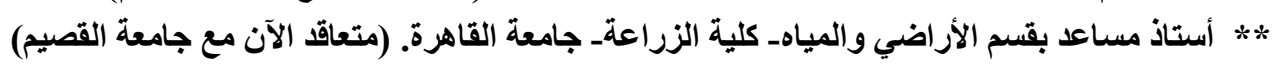




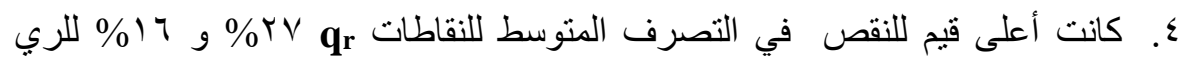

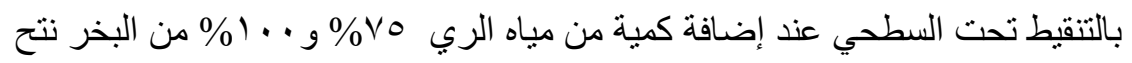

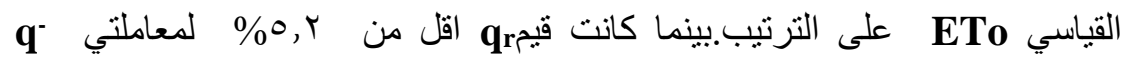

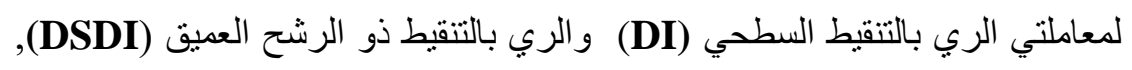
وذللك لجميع أعماق مياه الري المضافة.

๑. كانت أقل قيمة للتصرف النسبي للنقاطاتع VYR, , لمعاملة لري بالتتقيط تحت

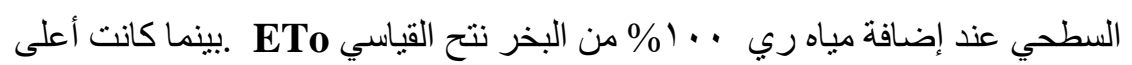

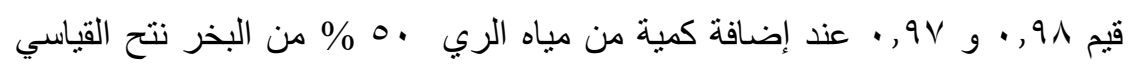

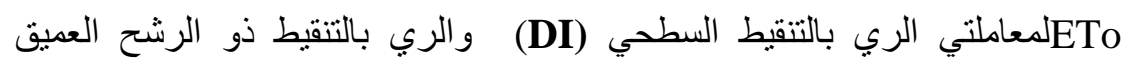
(DSDI)

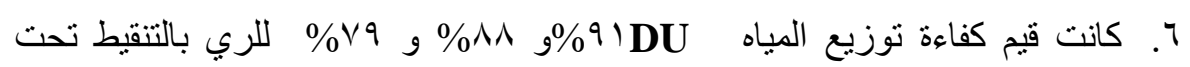

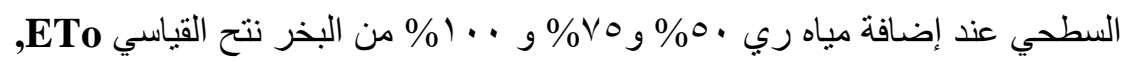

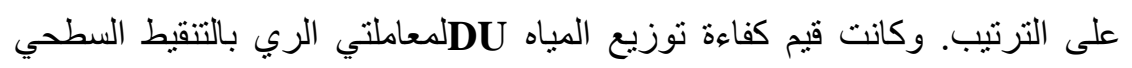
و الري بالتنقيط ذو الرشح العميق (DSDI) أعلى من القيم الخاصة بمعاملة الري بالتنقيط السطحي (DI), وذللك لجميع أعماق مياه الري المضافة.

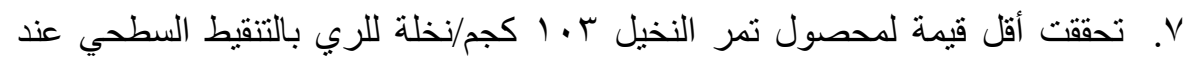

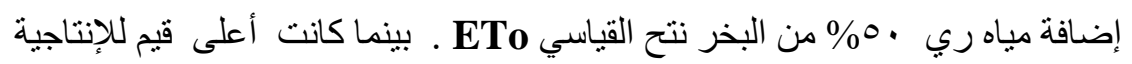

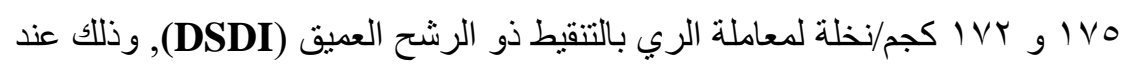

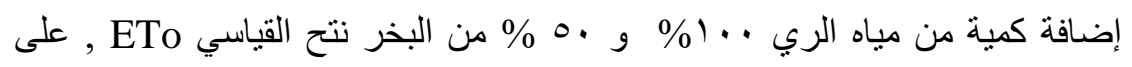
الترتيب.

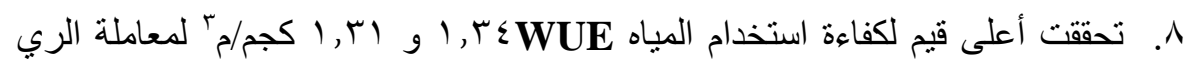

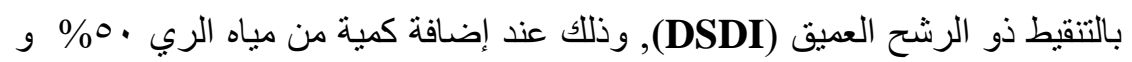

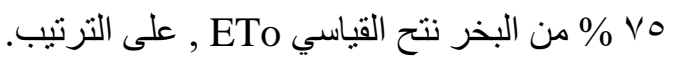

